\title{
SMALL BUSINESSES AND PUBLIC PROCUREMENT: SOME PROBLEMS OF CORRELATION
}

\author{
Anna Yu. Ryabova ${ }^{1}$ \\ Russian Post JSC \\ a.ria_1@mail.ru
}

\section{Abstract}

This paper is dedicated to the analysis of some problems small business entities face with in the field of public procurement. The field is regulated by laws made by the State. A lot of laws exist that regulate the functioning of small business entities. The laws made by the State to regulate the field of functioning of small business entities and their performance in the field of public procurement are numerous. Made laws are characterized as legal norms that do not comply with each other. The paper contains examples of such rules and shows negative effects for small business entities when they implement the right under consideration in the field of public procurement. The author classifies the issues according to the sector of public procurement and provides case studies concerning such issues including cases from the author's legal practice. The author makes practical recommendations in the conclusion of the paper.

\section{Keywords}

Law, problems of legislation, economy, the State, small business entity, individual entrepreneur, register of small businesses entity, public procurement, the state defense order, combining persons

\section{CONTENTS}

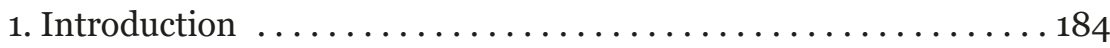

2. Regulatory framework for public procurement ............ 185

3. Case studies based on the author's practice showing the problems of small businesses in the field of public procurement........ 186

${ }^{1}$ Leading Specialist of the Procurement control Section of Russian Post JSC, Cand. Sci. (Law). 
3.1. Lack of information in the Unified Register of Small and Medium-Sized Business Entities ............... 186

3.2. Small businesses and procurement under the State Defense Order (SDO)................ 189

4. Other problems identified by the author in analysis of the official website on procurement........... 192

4.1. Restrictions on procurement at the initial (maximum) contract price............................ 192

4.2. Associations of entities acting on the side of a procurement participant and public procurement ................. 195

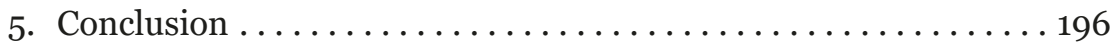

References ................................. 197

\section{Introduction}

The paper highlights the current problems of participation of a small business entity in public procurement (the term public purchase is also used as a synonym) in Russia. The COVID-19 pandemic, when many entities make decisions in favour of ceasing business activities due to lack of resources, has revealed the problem of participation of small business entities in public procurement and has prioritized this issue.

The purchase of goods, works and services for the State is carried out through special legislative procedures referred to as procurement. A minor part of the segment of procurement is reserved for small businesses.

The State has adopted various programs for the development of small businesses. However, they do not always achieve their goal. This paper provides examples to support this fact.

For small business entities the adoption of programs for their development is not as important as the presence of a correct legal framework for public procurement with the absence of bureaucratic barriers, bringing the law in line with the law on the development of small business. If the latest standards correlate with each other, the goal of developing the small business segment will be achieved.

This paper analyzes the problems arising from the legislation on public procurement faced with by small businesses. 


\section{Regulatory framework for public procurement}

Federal Law dated 24 July 2007, No 209-FZ “On the Development of Small and Medium Business in the Russian Federation" (hereinafter Federal Law No 209-FZ) is the fundamental law for small businesses that consolidates their definition, status and other important provisions. ${ }^{2}$

The main sources of the legal regulation of public procurement include Federal Law dated 5 April 2013, No 44-FZ "On the System of Public Procurement Contracts for Products, Work or Services for State Municipal Needs" (hereinafter Federal Law No 44-FZ). ${ }^{3}$ Federal Law No 44-FZ introduces the concept of procurement, identifies stages of procurement, and establishes their principles. Also, this Federal Law stipulates that the provisions contained in other instruments regulating these relations must comply with it. Thus, when considering the source of public procurement, it can be argued that Federal Law No 44-FZ is the fundamental instrument in this area.

This paper also analyzes Federal Law dated 18 July 2011, No 223FZ "On Procurement of Goods, Works and Services by Certain Types of Legal Entities" (hereinafter Federal Law No 223-FZ). ${ }^{4}$ For this study, the Law is interesting in terms of purchases that are carried out by state unitary enterprises. Such entities conduct purchases under Federal Law No 44-FZ and Federal Law No 223-FZ. The difference is in the source of funding for such purchases. Purchases made under Federal Law No 223-FZ are financed not from the state budget, but from the income raised by the enterprise as the result of its business activities.

${ }^{2}$ Federalnyy zakon ot 03.08.2018 No 313-FZ "O vnesenii izmeneniy v Federalnyy zakon "O razvitii malogo i srednego predprinimatelstva v Rossiyskoy Federatsii" [Federal Law of 3 August 2018 No 313-FZ "On Amendments to the Federal Law "On the Development of Small and Medium Business in the Russian Federation"]. URL: http://www.pravo.gov.ru (last visited Aug. 1, 2020).

${ }^{3}$ Federalnyy zakon ot 05.04.2013 No 44-FZ "O kontraktnoy sisteme v sfere zakupok tovarov, rabot, uslug dlya obespecheniya gosudarstvennykh i munitsipalnykh nuzhd" [Federal Law of 5 April 2013 No 44-FZ "On the contract system in the procurement of goods, works, services to meet state and municipal needs"]. URL: http://www.pravo.gov.ru (last visited Aug. 1, 2020).

${ }_{4}$ Federalnyy zakon ot 18.07.2011 No 223-FZ "O zakupkakh tovarov, rabot, uslug otdelnymi vidami yuridicheskikh lits" [Federal Law of 18 July 2011 No 223-FZ "On the procurement of goods, works, services by certain types of legal entities"]. URL: http:// www.pravo.gov.ru (last visited Aug. 1, 2020). 
If the State allows enterprises to make purchases under Federal Law No 223-FZ, certain provisions of this Law may be useful for Federal Law No 44-FZ. The author also illustrates this statement.

\section{Case studies based on the author's practice showing the problems of small businesses in the field of public procurement}

\subsection{Lack of information in the Unified Register of Small and Medium-Sized Business entities}

Under Federal Law No 44-FZ, customers are obliged to demand a declaration of belonging to the specified category of small business entities in procurement as a part of application. Participants involved, in turn, are obliged to declare their belonging to that category of entities. In this case, the customers have right to verify the information provided by participants.

The customers verify belonging to the category of small businesses entities using a special register. Such a register is maintained by an authorized state body. Under Article 4.1 of the Federal Law No 209-FZ this is the Federal Tax Service of Russia.

And what should customers do if there is no information in such registry? As an example I will describe the case from my practice. This case involves the decision of Moscow Federal Antimonopoly Service of 24 August 2017, in case No 2-57-10082/77-17 on violation of procurement legislation. ${ }^{5}$ In this case I was the secretary of the customer's commission for consideration of procurement applications and then represented interests of the customer in Antimonopoly Service (FAS). At the meeting of the commission, it was revealed that there was no information concerning one of the participants in the Register of Small and Medium-Sized Business Entities. Thus, the application

${ }_{5}$ Reshenie Federalnoy antimonopolnoy sluzhby po g. Moskve po delu No 2-5710082/77-17 o narushenii zakonodatelstva ob osushchestvlenii zakupok ot 24.08.2017 [The Decision of the Federal Antimonopoly Service in Moscow in case No 2-5710082/77-17 on violation of the procurement legislation dated 24 August 2017]. URL: http://zakupki.gov.ru/epz/complaint/quicksearch/search_eis.html?searchString=03 48100077717000053\&strictEqual=on\&fz94=on\&cancelled=on\&considered=on\&rega rded=on (last visited Aug. 1, 2020). 
of such participation was refused. The participant filed a complaint against the actions of the Customer. ${ }^{6}$

Representing the participant in the FAS I emphasized that the participant is not in the Register of small business entities. The FAS considered this argument sufficient to recognize the commission's actions as legitimate.

Federal Law No 313-FZ "On Amendments to the Federal Law "On the Development of Small and Medium Business in the Russian Federation" was adopted on 3 Aug. 2018.7 The Law corrected the concept of subjects of the analyzed category adding the mandatory presence of information about them in the Register of Small and Medium-Sized Businesses.

Accepting the amendment, the legislator did not take into account that for various reasons, information about the participant may not be available in the Register. These reasons can be divided in two groups.

The first includes subjective reasons, i.e. those that depend on the small business entity. For example, non-payment of mandatory payments. This leads to the fact that the State does not have information about such a procurement participant and, consequently, cannot enter information about it in the register. The fault of the procurement participant is obvious in this case.

The second group involves objective reasons that do not depend on the procurement participant. For example, various technical problems and system failures. This is not the fault of the procurement participant.

However, the customer's commission does not examine the reasons why the entity is not included in the Register. The entity that was rejected often also does not examine these reasons and does not appeal against customer's actions to higher authorities.

${ }^{6}$ Rezultat opredeleniya postavshchika, sformirovannyy na osnovanii razmeshchennykh protokolov [Vendor determination result, generated based on hosted protocols]. URL: https://zakupki.gov.ru/epz/order/notice/ea44/view/ supplier-results.html?regNumber $=0348100077717000053$ (last visited Aug. 1, 2020).

7 Federalnyy zakon ot 03.08.2018 No 313-FZ “O vnesenii izmeneniy v Federalnyy zakon "O razvitii malogo i srednego predprinimatelstva v Rossiyskoy Federatsii" [Federal Law of 03.08.2018 No 313-FZ “On Amendments to the Federal Law"]. URL: http://www.pravo.gov.ru (last visited Aug. 1, 2020). 
Such actions do not contribute to the development of small business. Thus, the achievements in this field declared by the government cannot be called reliable and effective.

Here, it is important to minimize all factors due to which the rights of participants in all legal relations and of small businesses cannot be implemented. At the same time, it is important to understand that there is a direct connection between the problems in the economy that the state must solve and the level of business development. We should agree with the view that "The state plays a special role in supporting small businesses, as the development of small businesses will help solve the problems of unemployment, increase labor productivity, saturate the market with innovative innovations, and solve issues related to the inflationary instability of the Russian economy."

Therefore, it is important for the state to find problems and take measures to solve them, as well as to try to anticipate, when making certain decisions, difficulties that may provoke a result different from the one that is planned to be achieved.

It is needed to indicate another problem that arises as a result of the rejection of the procurement participant due to the lack of information about her in the Register. It is appropriate to refer to Para 27 of Article 44 of Federal Law No 44-FZ. It establishes the rule that if during one quarter of a calendar year on the same electronic platform in respect of three or more bids filed by a procurement participant, the commissions made decisions concerning their non-compliance with the requirements of Federal Law No 44-FZ, the funds, blocked on the special account of the procurement participant in the amount of the security for each third of such an application, are subject to transfer to the appropriate budget of the budget system of the Russian Federation.

And the situation is quite real because the state provides for its needs through the procurement mechanism, when the participant in the procurement is rejected three times in one quarter due to lack of

8 TA Glinova, Problemy razvitiya malogo biznesa v Rossii [Problems of development of small business in Russia]. 8 Nauchno-metodicheskiy elektronnyy zhurnal "Kontsept" [Scientific and methodological electronic journal "Kontsept"] (2015). URL: http://e-koncept.ru/2015/15266.htm (last visited Aug. 1, 2020). 
information about the procurement participant in the Register. This, in turn, entails financial encumbrances.

Ideally, financial encumbrances should be justified and applied on clear and logical grounds. From the point of view of small business participants, the current situation discriminates against them. The state has moved to the rails of procurement. For entrepreneurs, participation in procurement is the best way to survive. However, for entrepreneurs represented by their small entities it is almost impossible to survive.

\subsection{Small businesses and procurement under the State Defense Order (SDO)}

Federal Law No 44-FZ does not provide an explanation as to who the small business entities are and who may be a participant in procurement in the field of the State Defense Order (SDO). To do this, you need to refer to special rules.

Under Federal Law No 209-FZ small business entities include legal entities and individual entrepreneurs. Therefore, if the purchase is made among small businesses, any person from this category can participate in the procedure.

Under Para 3 of Article 3 of Federal Law dated Dec. 29 2007, No 275-FZ "On the State Defense Order" (hereinafter Federal Law No 275-FZ), only legal entities participate in purchases that are made at the expense of the limits of budget obligations allocated for the implementation of the policy within of the SDO. ${ }^{9}$

Thus, individual entrepreneurs should be excluded from the total number of participants in purchases that are carried out within the framework of the SDO.

At the same time the purchase within the state defense order does not always include the supply of military complex equipment. It also covers, for example, the supply of low-freezing glass-washing liquid, repairs of office equipment, which may well be carried out by individuals belonging to individual entrepreneurs.

9 Federalnyy zakon ot 29.12.2012 No 275-FZ "O gosudarstvennom oboronnom zakaze" [Federal Law dated 29 December 2012 No 275-FZ "On the State Defense Order”]. URL: http://www.pravo.gov.ru (last visited Aug. 1, 2020). 
In this regard, when conducting such minor purchases under the SDO, customers have a direct obligation to reject applications that are submitted by individual entrepreneurs under the threat of administrative punishment in the amount of 1 percent of the initial (maximum) contract price, but not less than five thousand rubles and not more than thirty thousand rubles. Administrative responsibility is established under Part 2 Article 7.30 of the Code of Administrative Offences of the Russian Federation. ${ }^{10}$ As an example, I will cite purchases within the framework of the SDO from my practice, for which individual entrepreneurs were rejected.

Purchase for the supply of cartridges for organizational equipment. The procurement notification was posted on 16 March 2018 No 0348100077718000016. ${ }^{11}$ Three applications were submitted. Two of them were filed by legal entities and one by an individual entrepreneur. The last participant was rejected, as it failed to comply with the rules of the Federal Law No 275-FZ.

Purchase for the supply of low-freezing glass-washing liquid. The notification was posted on 28 September 2017 No $0348100077717000075 .{ }^{12}$ Two applications were submitted from individual entrepreneurs. By law, the customer rejected them, and the auction was declared invalid. This required re-conducting the purchase, which increased the timing of both the purchase and delivery of the product.

${ }^{10}$ Kodeks Rossiyskoy Federatsii ob administrativnykh pravonarusheniyakh ot 30.12.2001 No 195-FZ [Code of the Russian Federation on Administrative Offenses dated 30 December 2001 No 195-FZ]. URL: http://www.pravo.gov.ru (last visited Aug. 1, 2020).

${ }^{11}$ Izveshchenie ot 16.03 .2018 No 0348100077718000016 na postavku kartridzhey $\mathrm{k}$ organizatsionnoy tekhnike [Notification 16 March 2018 No 0348100077718000016 for the supply of cartridges for organizational equipment]. URL:http://zakupki.gov.ru/epz/order/notice/ea44/view/protocol/protocol-bid-list. html?regNumber=0348100077718000016\&protocolId=17990187 (last visited Aug. 1, 2020).

${ }^{12}$ Izveshchenie ot 28.09.2017 No 0348100077717000075 na postavku nizkozamerzayushchey stekloomyvayushchey zhidkosti [Notification dated 28 September 2017 No 0348100077717000075 for the supply of low-freezing windshield washer fluid]. URL: http://zakupki.gov.ru/epz/order/notice/ea44/view/ supplier-results.html?regNumber $=0348100077717000075$. 
As a result of such actions on the part of the legislator, both the State in the face of customers and the vulnerable layer in the face of procurement participants remain unsatisfied.

In this situation it is necessary to make adjustments to the current legislation and try to solve the problem. In particular, it is acceptable to use the classifier of goods, works, services, based on their complexity, innovation, and technology to make a choice among all participants or without individual entrepreneurs.

The second problem with this question is the following. The situation is obvious when a legal entity has only one employee. This only employee acts as the CEO. He participates in the procurement, which is carried out under the SDO among small businesses. According to the law such a participant should be accepted. However, indifference is obvious when you compare it with an individual entrepreneur. The only difference between them is in their legal form. There is a legitimate question why there is a legislative imperfection when an individual entrepreneur is rejected, but a legal entity consisting of 1 person is accepted.

The third negative aspect was revealed above in the analysis of Part 27 of Article 44 of Federal Law No 44-FZ.

Discussions about procurement have been going on for a long time in the scientific sphere. Scientists with extensive experience in procurement still face a number of challenges. In their discussion of public procurement Snider and Rendon write that "Scholars have yet to give sufficient efforts to the sort of conceptual theorising about policy that will lead to ordering devices and approaches that can help researchers and students make sense of its complexity, uses and limitations." ${ }^{13}$

McCue and Prier write about using theoretical works too when "One wants to explain, predict, and understand behavior concerning the intent, purpose, and actual use of cooperatives in procurement."14

${ }^{13}$ KF Snider \& RG Rendon, Public Procurement Policy: Implications for Theory and Practice, 8 (3) Journal of Public Procurement 311 (2008).

${ }_{14} \mathrm{C}$ McCue \& E Prier, Using Agency Theory to Model Cooperative Public Purchasing, 8 (1) Journal of Public Procurement 1 (2008). 
As for Russia such fundamental works are absent. The field of procurement is developing rather slowly and inconsistently in Russia. The legislator, in turn, tries to get ahead of science, theory, in connection with which such inconsistencies arise. Another factor in the presence of problems is a non-systematic approach to the adoption of laws. And if science in terms of procurement is developing slowly, then the legislator could avoid the existing problems if he carefully approaches the adoption of laws.

Law should not be perceived as a means of tightening and restricting. The question arises about the performance of the regulatory function by law. Science does not dispute the fact that this function of law is a direction of influence of law on social relations, which is designed to provide a certain level of social order that most fully expresses the essence of law, as well as its relationship with other phenomena of social reality. The legislator misrepresented the essence of this function questioning the positive result of the policy.

\section{Other problems identified by the author in analysis of the official website on procurement}

\subsection{Restrictions on procurement at the initial (maximum) contract price}

Under Para 1 of Part 1 of Article 31 of Federal Law No 44-FZ, procurement made among small businesses at the initial (maximum) contract price must not exceed twenty million rubles. In this regard the question arises, are such participants in legal relations not able to fulfill a more expensive procurement?

The answer could be affirmative but for the provisions of Federal Law No 223-FZ that does not set restrictions on the initial (maximum) price.

After analyzing the information published in the Unified Information System in Procurement, it is concluded that the legislator underestimated the potential of procurement participants under Federal Law No 44-FZ by setting the upper limit of the initial (maximum) contract price. "Procurements is an important part of economic 
activities encompassing in general public expenditures on goods, services and works. ${ }^{15}$

Therefore, it is not quite correct to split procurements for small businesses. The legislator can take one of the following paths.

The first path is to fix the upper limit of the initial (maximum) contract price in the law. This limit should be higher than it is currently set. And give the customer the right to choose whether to use this range in a particular procurement. The second option is to reject the upper limit of the initial (maximum) contract price or set a higher price.

To confirm the relevance of what has been said, we give examples. The customer, being a state unitary enterprise, carries out procurement according to the rules of federal Law No 223-FZ among the studied category. It should be noted that procurements under the provisions of this law are carried out among both small and medium businesses. The subject of the procurement is the application of horizontal road markings on public roads of regional or inter-municipal significance. The initial (maximum) contract price was 31514585.00 rubles. ${ }^{16}$

Another customer carries out procurement among small businesses in accordance with the Federal Law No 44-FZ. The subject of the procurement is similar, it is the application of horizontal road markings on public roads of regional and (or) inter-municipal significance. The initial (maximum) contract price is 18310518.00 rubles. ${ }^{17}$

Because of the restrictions established by Federal Law No 44-FZ on the initial (maximum) price of the contract the customer must split the procurement and on the same day place two more notifications on

${ }_{15}$ H Handler, Strategic Public Procurement: An Overview, URL: https://www. researchgate.net/publication/284725763_Strategic_Public_Procurement_An_ Overview (last visited Aug. 1, 2020).

${ }^{16}$ Izveshchenie ot 14.04.2020 No 32009077746 [Notification dated 14 April 2020 No 32009077746], URL: https://zakupki.gov.ru/223/purchase/public/purchase/ info/common-info.html?regNumber $=32009077746$ (last visited Jul. 4, 2020).

${ }_{17}$ Izveshchenie ot 29.04.2020 No 0338200008720000008 [Notification dated 29 April 2020 No 0338200008720000008], URL: https://zakupki.gov.ru/epz/ order/notice/ea44/view/common-info.html?regNumber $=0338200008720000008$ (last visited Jul. 4, 2020). 
a similar subject among small businesses. The price of one of them is 14748347.00 rubles..$^{18}$ The price of other is 15124479.00 rubles..$^{19}$

It should be noted that the winner for all these purchases is the same individual entrepreneur Ildus Akhmadullin.

Thus, the customer under Federal Law No 44-FZ is forced to conduct more procedures in comparison with the terms of procurement based on federal Law No 223-FZ.

The legislator does not take into account the amount of expenses for himself (since the customer is the state represented by the relevant state body): specialists who must prepare documentation, time spent on approving documentation and conducting expertise, supporting documentation from the stage of entering into the schedule and ending with the stage of contract execution with a huge paperwork in terms of preparing and analyzing submitted applications for participation in each procurement, preparing protocols, potential complaints (the number of possible complaints is directly proportional to the number of purchases), etc.

It should agreed with the view that "a need for research on supplier incentives at a market level, on the post contract management of suppliers and as an important sub-set, key supplier relationship management, along with professional development." ${ }^{20}$

As a result of the legislator's actions small businesses are not stimulated or developed. Accordingly, the economy is not developing, too. It is more rational to review the provisions of Federal Law No 44FZ concerning the upper limit of the initial (maximum) contract price for procurements among small businesses.

${ }^{18}$ Izveshchenie ot 29.04.2020 No 0338200008720000009 [Notification dated 29 April 2020 No 0338200008720000009$],$ URL: https://zakupki.gov.ru/epz/order/ notice/ea44/view/supplier-results.html?regNumber=0338200008720000009, (last visited Jul. 4, 2020).

19 Izveshchenie ot 29.04.2020 No 0338200008720000010 [Notification dated 29 April 2020 No 0338200008720000010], URL: https://zakupki.gov.ru/epz/order/ notice/ea44/view/supplier-results.html?regNumber $=0338200008720000010$ (last visited Jul. 4, 2020).

${ }^{20}$ Nigel Caldwell, Helen Walker, Christine Harland, Louise Knight, Jurong Zheng \& Tim Wakeleyb, Promoting competitive markets: The role of public procurement, 11 (5-6) Journal of Purchasing and Supply Management 243 (September-November) 20050. 


\subsection{Associations of entities acting on the side of a procurement participant and public procurement}

Under Part 1 Article 3 of Federal Law No 44-FZ, a procurement participant is any legal entity or any individual, including one registered as an individual entrepreneur.

According to the norms of article 3 of the Act No 223-FZ a procurement participant is any legal entity or several legal entities acting on the side of one procurement participant, or any individual or several individuals acting on the side of one procurement participant, including an individual entrepreneur or several individual entrepreneurs acting on the side of one procurement participant.

The difference between these concepts is quite obvious. Federal Law No 223-FZ has established the possibility to use the methods provided for by current legislation for combining persons for joint activities in procurement.

According to Federal Law No 44-FZ, participation in procurement is only possible for a single person.

It is not very clear how this decision of the legislator is justified. It is legal for procurement participants to join together, and there are no obstacles in terms of civil law to establish such a possibility in procurement conducted according to Federal Law No 44-FZ.

It is permissible for procurement under Federal Law No 44-FZ to remove the upper range of the price and introduce the formulation of the participant of the procurement not only as an independent entity or a legal entity, but supplementing it as an association of such entities.

As stressed by Laffont and Tirole, to investigate a theory of procurement one should take into consideration three main types of regulatory constraints: informational, transactional, and administrative and political. ${ }^{21}$

The State has the right to establish and regulate these restrictions. The State will be required to adjust Federal Law No 44-FZ in terms of the procedure for submitting documents from several persons acting on

${ }^{21} \mathrm{~J}-\mathrm{J}$ Laffont \& J Tirole. A theory of incentives in procurement and regulation, URL: https://link.springer.com/article/10.1007/s40812-018-0091-3\#ref-CR2 (last visited May 02, 2020). 
the side of one participant. It is quite clear that for some procurements small businesses may lack resources, production capacity and personnel for objective reasons. The introduction of a form of combining several persons on the side of one procurement participant will solve this problem. Moreover, the studied category of subjects can participate in competitions held for any category of participants according to Federal Law No 44-FZ and compete with large enterprises, since not all competitions can be attended by small businesses according to the current legislation. In order to be a small business entity the law sets limit on the number of employees. Customers often set requirements for purchasing participants to have more than 100 employees working under employment contracts. The customer by virtue of Federal Law No 44-FZ is not obliged to justify the evaluation criteria set by it for participation in the competition. Thus small businesses are excluded from procurement which is not entirely reasonable.

Another possibility to unreasonably exclude small businesses from procurement is to set a parameter rating based on the maximum offer from the offers made by the procurement participants based on the evaluation criteria. It is quite obvious that when a large participant and a small business entity are fighting, the latter's chances of winning are much lower.

\section{Conclusion}

The above problems both from the author's direct practice and the problems identified by the author in the analysis of ongoing procurement process show that under current legislation, procurement participants belonging to the category of small businesses face a number of difficulties that can be avoided if the legislator properly models the law. Current realities indicate that the State does not seek to eliminate existing problems. And the state is only required to adjust the current legislation.

This applies to the coordination of the concept of a small business entity in general and a small business entity as participants of procurements carried out within the state defense order. This is also an adjustment of the legislation on the SDO by changing the object of 
procurement, namely, the target nature of limits for the procurement of simple objects, such as are presented in the examples given in this paper.

It seems real to consolidate in Federal Law No 44-FZ the provision that procurement participants can be combining persons under the rules of civil law for joint activities in procurement, which will make procurements more competitive on the one hand, on the other - the customer will get a better result, since it will employ more people with different opinions and opportunities.

Changing the current legislation, in turn, will raise the level of the economy. This is an important factor for the development of business and the State.

\section{REFERENCES}

1. McCue C. \& Prier E. Using Agency Theory to Model Cooperative Public Purchasing, 8 (1) Journal of Public Procurement 1 (2008).

2. Handler H. Strategic Public Procurement: An Overview, URL: https://www.researchgate.net/publication/284725763_Strategic _ Public_Procurement_An_Overview (last visited Aug. 01, 2020).

3. Laffont J-J. \& Tirole J. A theory of incentives in procurement and regulation, URL: https://link.springer.com/article/10.1007/s40812018-0091-3\#ref-CR2 (last visited May 02, 2020).

4. Snider KF. \& Rendon RG. Public Procurement Policy: Implications for Theory and Practice, 8 (3) Journal of Public Procurement 311 (2008).

5. Caldwell N., Walker H., Harland Ch., Knight L., Jurong Zheng \& Wakeleyb T. Promoting competitive markets: The role of public procurement, 11 (5-6) Journal of Purchasing and Supply Management 243 (September-November 2005).

6. Glinova TA. Problemy razvitiya malogo biznesa v Rossii [Problems of development of small business in Russia]. 8 Nauchno-metodicheskiy elektronnyy zhurnal "Kontsept" [Scientific and methodologicalelectronic journal "Kontsept"] (2015). URL: http://e-koncept.ru/2015/15266.htm (last visited Aug. 01, 2020). (In Russ.) 